\title{
PENGARUH PENGGUNAAN MODEL PEMBELAJARAN KOOPERATIF TIPE STUDENT TEAMS ACHIEVEMENT DIVISION (STAD) TERHADAP HASIL BELAJAR BIOLOGI
}

\author{
Yendrita dan Neti Soprina \\ STKIP Yayasan Abdi Pendidikan Payakumbuh \\ yen29drita@gmail.com
}

\begin{abstract}
This study aims to determine the effect of cooperative learning model of Student Team Achievement Division (STAD) type on students of class X SMK Negeri 1 Talamau West Pasaman District. This research is a quasi experiment with Posttest-Only Control Design research design. Population in this research is all class X SMKN I Talamau. The sample was 2 classes with random sampling technique, Class X ATP1 as experiment class and APH class as control class. The research instrument is an objective test. The data were analyzed by $t$ test. Based on the results of data analysis obtained $t_{\text {hitung }}=2.23$ and $t_{\text {table }}=1.70$ at the real level of 0.05, means hypothesis is accepted at $95 \%$ confidence level. Thus it can be concluded that there is influence of the use of cooperative learning model Student Teams Achievement Division (STAD) type in class X SMK Negeri 1 Talamau Pasaman Barat Discrict.
\end{abstract}

Keywords: STAD, Learning outcomes of biology

\begin{abstract}
ABSTRAK
Penelitian ini bertujuan untuk mengetahui pengaruh model pembelajaran kooperatif tipe Student Team Achievemen Division (STAD) pada siswa kelas X SMK Negeri 1 Talamau Kabupaten Pasaman Barat. Penelitian ini merupakan quasi eksperimen dengan rancangan penelitian Posttest-Only Control Design. Populasi dalam penelitian ini adalah seluruh kelas X SMKN I Talamau. Sampel penelitian sebanyak 2 kelas, deambil dengan teknik random sampling, kelas $\mathrm{X}$ ATP1 sebagai kelas eksperimen dan kelas APH sebagai kelas kontrol. Instrumen penelitian ini berupa seperangkat tes. Data dianalisis dengan uji t. Dari hasil analisis data diperoleh $\mathrm{t}_{\text {hitung }}=2,23$ dan $\mathrm{t}_{\text {tabel }}=1,70$ pada taraf nyata 0,05 , berarti hipotesis diterima pada taraf kepercayaan $95 \%$. Dengan demikian dapat disimpulkan bahwa terdapat pengaruh penggunaan model pembelajaran kooperatif tipe Student Teams Achievement Division (STAD) pada kelas X SMK Negeri 1 Talamau Kabupaten Pasaman Barat.
\end{abstract}

Kata Kunci : STAD, Hasil Belajar Biologi.

\section{PENDAHULUAN}

Berdasarkan Undang-undang No. 20 Tahun 2003 tentang Sistem Pendidikan Nasional pasal 1 ayat 1 yaitu: Pendidikan adalah usaha sadar dan terencana untuk mewujudkan suasana belajar dan proses pembelajaran agar peserta didik secara aktif mengembagkan potensi dirinya untuk memiliki kekuatan spritual keagamaan, pengendalian diri, kepribadian, kecerdasan, akhlak mulia, serta keterampilan yang diperlukan dirinya, masyarakat, bangsa, dan negara (Trianto, 2010:3). 
Dengan demikian, peranan guru baik sebagai motivator, maupun sebagai fasilitator dalam proses pembelajaran, sangatlah menentukan dalam ketercapaian tujuan Pendidikan Nasional. Dalam proses pembelajaran terjadi interaksi antara guru dan peserta didik. Di antara keduanya terjadi komunikasi yang terarah menuju suatu tujuan yang telah ditetapkan. Pada proses pembelajaran guru harus mampu menciptakan suasana yang kondusif dan memberikan motivasi yang besar pada siswa untuk mengikuti pembelajaran secara aktif dan kreatif.

Berdasarkan observasi dilakukan, ternyata proses pembelajaran pada mata pelajaran biologi di SMK N I Talamau, belum bisa melibatkan siswa secara maksimal, mungkin hal ini merupakan salah satu penyebeb rendahnya hasil belajar Biologi siswa di SMK N 1 Talamau.dan juga masih banyaknya siswa yang belum mencapai Ketuntasan Minimal. Nilai KKM yang ditetapkan di SMK N Talamau yaitu 75. Hal ini dilihat dari nilai rata-rata Ujian Semester I Kelas X Tahun Pelajaran 2016/2017.

Tabel I. Nilai Rata-rata Ujian Semester I Kelas X SMK N 1 Talamau

\begin{tabular}{|c|c|c|c|c|c|c|}
\hline $\begin{array}{c}\text { Kelas } \\
(\mathbf{X})\end{array}$ & $\begin{array}{c}\text { Juml } \\
\text { ah } \\
\text { Siswa }\end{array}$ & $\begin{array}{c}\text { Nil } \\
\text { ai } \\
\text { rat } \\
\text { a- }\end{array}$ & $\begin{array}{c}\text { Sisw } \\
\mathbf{a} \\
\text { Tun } \\
\text { tas }\end{array}$ & $\begin{array}{c}\text { rat } \\
\text { Siswa } \\
\text { tidak } \\
\text { tuntas }\end{array}$ & $\begin{array}{c}\text { Siswa tidak } \\
\text { tuntas }\end{array}$ & $\begin{array}{c}(\%) \text { siswa tidak } \\
\text { tuntas }\end{array}$ \\
\hline ATU & 13 & 64 & 5 & $38 \%$ & & \\
\hline ATR & 12 & 62 & 5 & $42 \%$ & 7 & $62 \%$ \\
\hline ATP1 & 17 & 63 & 7 & $41 \%$ & 10 & $58 \%$ \\
\hline ATP2 & 20 & 61 & 8 & $40 \%$ & 12 & $69 \%$ \\
\hline ATH & 14 & 63 & 6 & $43 \%$ & 8 & $57 \%$ \\
\hline APH & 18 & 62 & 8 & $44 \%$ & 10 & $56 \%$ \\
\hline Jumlah & $\mathbf{9 4}$ & $\mathbf{6 3}$ & $\mathbf{3 9}$ & $\mathbf{4 1 \%}$ & $\mathbf{5 5}$ & $\mathbf{5 9 \%}$ \\
\hline
\end{tabular}

Sumber: Tata Usaha SMK N 1 Talamau

Keterangan:

ATU: Agribisnis Ternak Unggas

ATR: Agribisnis Ternak Ruminansia

ATP: Agribisnis Tanaman Perkebunan

ATH: Agribisnis Tanaman Hortikultura

APH:Agribisnis Pengolahan Hasil Pertanian

Berdasarkan nilai rata-rata ujian semester 1 yang masih rendah, tingkat ketuntatasan, dan hasil belajar mata pelajaran biologi kelas X SMK N I Talamau tersebut, maka salah satu alternatif pemecahan masalanya adalah melaksanakan pembelajaran dengan mempergunakan model pembelajaran kooperatif, salah satu model pembelajaran kooperatif yang dapat dipergunakan dalam pembelajaran biologi adalah model STAD. Student Teams Achievement Divisions (STAD) adalah model pembelajaran kooperatif yang memberikan kesempatan kepada siswa untuk belajar secara tim atau kelompok dan mengukur kemampuannya sendiri secara individu setelah belajar secara tim.

Keunggulan tipe STAD dibandingkan dengan pembelajaran kooperatif lain yaitu STAD merupakan pembelajaran kooperatif yang paling sederhana, dan merupakan model yang paling baik untuk permulaan bagi guru yang baru 
menggunakan pendekatan kooperatif (Slavin) dalam (Nurhamni: 2013). Oleh sebab itu, penulis tertarik untuk melakukan penelitian yang berjudul: Pengaruh Penggunaan Model Pembelajaran Kooperatif Tipe Student Teams Achievement Division (STAD) Terhadap Hasil Belajar Biologi Siswa Kelas X SMK Negeri 1 Talamau Kabupaten Pasaman Barat.

Rumusan masalah dalam penelitian ini adalah Apakah terdapat pengaruh penggunaan model pembelajaran kooperatif tipe Student Teams Achievement Division (STAD) terhadap hasil belajar biologi kelas X SMK N I Talamau Kabupaten Pasaman Barat? Hipotesis penelitiannya adalah: Terdapat pengaruh yang signifikan dari penggunaan model pembelajaran kooperatif tipe Student Teams Achievement Division (STAD) terhadap hasil belajar biologi kelas X SMK N I Talamau Kabupaten Pasaman Barat. Student team Achievement Division (STAD) merupakan salah satu metode pembelajaran kooperatif yang paling sederhana dan paling baik untuk permulaan bagi para guru yang baru menggunakan pendekatan kooperatif, model ini dikembangkan oleh R.Slavin.

Model kooperatif tipe STAD ini mudah digunakan bagi para guru pemula karena mudah dipahami dan dapat diterapkan pada siswa dengan kemampuan tinggi, sedang, dan rendah. Model pembelajaran ini terdiri atas lima komponen utama yaitu presentasi kelas, tim, kuis, skor kemajuan individual, dan rekognisi tim.

Presentasi kelas merupakan fase memperkenalkan materi pelajaran kepada siswa. Pengajaran ini dipimpin oleh guru seperti pengajaran biasa, namun berfokus pada unit STAD. Selanjutnya siswa akan mengerjakan tugas secara kelompok dan bisa saling membantu, selanjutnya siswa akan diberi kuis secara individu dan tidak ada lagi bekerja sama dalam kelompok, hal ini akan membuat siswa menyadari bahwa mereka harus memberi perhatian penuh pada presentasi kelas, sehingga dapat membantu mereka dalam mengerjakan kuis yang nantinya skor kuis akan menentukan skor tim mereka.

Tim terdiri dari empat sampai lima siswa yang mewakili seluruh bagian dari kelas dalam hal kinerja akademik, jenis kelamin, ras dan etnisitas. Fungsi utama tim adalah memastikan bahwa semua anggota tim benar-benar belajar dan dapat mengerjakan kuis dengan baik.

Kuis individual akan dilakukan setelah satu sampai dua periode presentasi guru dan satu atau dua periode praktik tim. Tiap mahasiswa harus betanggung jawab secara individual untuk memahami materinya.

Skor kemajuan individual digunakan untuk memberikan gambaran kepada siswa apa yang harus dicapai dan memberi gambaran kinerja yang diharapkan terus meningkat dari sebelumnya. Dalam sistem skor ini, setiap siswa dapat memberi kontribusi poin yang maksimal kepada timnya. Sedangkan skor tim didapatkan dari kontribusi poin individu.

Rekognisi tim merupakan penghargaan kepada siswa apabila skor rata-rata mereka mencapai kriteria tertentu. Skor tim siswa dapat juga digunakan untuk menentukan dua puluh persen dari peringkat mereka.

Jadi berdasarkan penjabaran diatas, model kooperatif tipe STAD dapat disimpulkan sebagai model pembelajaran kooperatif dimana siswanya dibagi dalam kelompok yang beranggotakan 4-5 orang secara heterogen. Tahap pembelajaran kooperatif tipe STAD terdiri dari 6 fase yaitu; menyampaikan tujuan dan memotivasi siswa, menyajikan atau menyampaikan informasi, 
mengorgani-sasikan siswa dalam kelompok belajar, membimbing kelompok belajar dan bekerja, evaluasi, memberikan penghargaan.

Kelebihan dalam penggunaan model pembelajaran STAD antara lain arah pelajaran lebih jelas dan terarah karena guru menjelaskan uraian materi yang akan dipelajari ditahap awal, belajar lebih menyenangkan, meningkatkan kerjasama antar siswa, meningkatkan semangat belajar siswa dengan adany kuis, dan guru dapat mengetahui kemampuan dan keberhasilan siswa dalam menyerap materi pelajaran.

Sedangkan kekurangan dari model ini adalah kesulitan yang dapat ditemui guru dalam membagi kelompok heterogen, selain itu kelompok heterogen memiliki potensi munculnya ketidakcocokan antara siswa dalam satu kelompok, dalam diskusi terdapat kemungkinan adanya siswa yang menjadi pelengkap dalam kelompok karena tugas dikerjakan oleh sebagian anggotanya saja, dan dalam evaluasi sering kali siswa mencontek sehingga hasil evaluasi tidak murni dari kemampuannya.

\section{METODOLOGI}

Populasi penelitian ini adalah siswa kelas X SMK N I Talamau yang terdiri dari 6 kelas sebagaimana yang telah dijelaskan sebelumnya. Penelitian ini memerlukan 2 kelas sampel. Setelah dilakukan uji homogenitas, ternyata semua kelas mempunyai kemampuan yang homogen, maka sampel ditarik secara random sampel, ternyata kelas Agrobisnis Tanaman Perkebunan I (ATP) I terpilih sebagai kelas Eskperimen yang pembelajarannya dilakukan dengan menggunakan model Student Teams Achievement Division (STAD dan Kelas Agrobisnis Pengolahan Hasil Pertanian (APH) sebagai kelas kontrol

Jenis penelitian ini adalah eksperimen semu, karena tidak semua variabel dapat dikontrol dengan ketat. Variabel dalam penelitian ini terdiri dari dua variabel yaitu variabel bebas dan variabel terikat. Variabel bebasnya adalah penggunaan model pembelajaran kooperatif tipe Student Teams Achievement Division (STAD) dalam pembelajaran Biologi dan variabel terikatnya adalah hasil belajar pada ranah kognitif.

Jenis datanya adalah data primer yaitu berupa hasil belajar yang langsung diperoleh dari hasil belajar siswa pada kedua kelas sampel.Instrumen penelitian ini berupa seperangkat tes dengan materi Protista. Sebelum dijadikan sebagai alat pengumpul data, maka terlebih dahulu telah diujicobakan kepada siswa Agrobisnis tanaman pertanian 2 yang telah terlebih dahulu mempelajari materi tersebut.

Pelaksanaan penelitian ini dilaksanakan langsung oleh guru bidang studi Biologi pada kelas sampel, dimana pembelajaran pada kelas eksperimen disediakan oleh peneliti. Sebelum penelitian dimulai, maka terlebih dahulu guru dan siswanya telah dilatih untuk mempergunakan model STAD pada materi lain. Pembelajaran pada kelas kontrol dilakukan juga oleh gurunya sendiri dan begitu juga dengan perangkat dan metode pembelajarannya hanya mempergunakan perangkat dan metode pembelajaran yang biasa digunakan oleh guru bidang studi biologi di kelas tersebut. 


\section{HASIL PENELITIAN}

\section{Uji Normalitas}

Untuk melihat apakah data sampel berasal dari populasi yang berdistribusi normal, maka dilakukan uji normalitas dengan menggunakan uji Lilifors pada taraf nyata 0,05 seperti pada Tabel berikut ini:

Tabel 2. Hasil Uji Normalitas Kelas Eksperimen dan Kontrol

\begin{tabular}{|r|c|c|c|c|c|c|}
\hline No & Kelas & $\mathbf{N}$ & $\boldsymbol{\alpha}$ & $\mathbf{L}_{\mathbf{0}}$ & $\mathbf{L}_{\mathbf{t}}$ & Keterangan \\
\hline $\mathbf{1}$ & Eksperimen & 16 & 0,05 & 0,0478 & 0,213 & Normal \\
\hline $\mathbf{2}$ & Kontrol & 17 & 0,05 & 0,1148 & 0,206 & Normal \\
\hline
\end{tabular}

Hasil Uji nomalitas dari kedua sampel yang terdapat pada tabel diatas menyatakan nilai Lo kelas eksperimen $=0,0478$ dan kontrol $=0,1148$, sedangkan nilai $\mathrm{L}_{\mathrm{t}}$ kelas kontrol $=0,213$ dan kontrol $=0,206$. Dengan demikian dapat dikatakan bahwa Lt > Lo, berarti data pada kedua kelas sampel berdistribusi normal. Untuk lebih lengkapnya dapat dilihat

\section{Uji Homogenitas}

Uji homogenitas bertujuan untuk mengetahui apakah kedua kelompok data mempunyai varians yang homogen atau tidak, untuk menguji homogenitas dilakukan uji F. Hasil uji homogenitas kedua kelompok data dapat dilihat pada Tabel berikut ini.

Tabel 3. Hasil Uji Homogenitas

\begin{tabular}{|c|c|c|c|c|c|}
\hline Kelas & $\mathbf{S}$ & $\mathbf{S}^{\mathbf{2}}$ & $\mathbf{F}_{\text {hitung }}$ & $\mathbf{F}_{\text {tabel }}$ & Kesimpulan \\
\hline Eksperimen & 13,61 & 185,232 & 1,12 & 2,33 & Homogen \\
\hline Kontrol & 12,81 & 164,096 & & & \\
\hline
\end{tabular}

Dari hasil uji homogenitas terlihat $\mathrm{F}_{\text {hitung }}=1,12$ sedangkan $\mathrm{F}_{\text {tabel }}=2,33$ (pada taraf nyata 0,05). Dengan demikian dapat dinyatakan bahwa kedua kelompok data mempunyai varians yang homogen karena $\mathrm{F}_{\text {tabel }}>\mathrm{F}_{\text {hitung, }}$

\section{Uji Hipotesis}

Uji hipotesisi dilakukan dengan menggunakan uji t. Hasil uji t dapat dilihat pada Tabel berikut.

Tabel 4. Hasil Uji Hipotesis Kelompok Data

\begin{tabular}{|c|c|c|c|c|c|c|}
\hline Kelas & $\mathbf{N}$ & $\mathbf{X}$ & $\mathbf{s}$ & $\mathbf{T}_{\text {hitung }}$ & $\mathbf{t}_{\text {tabel }}$ & Kesimpulan \\
\hline Eksperimen & 16 & 73 & 13,20 & 2,23 & 1,70 & $\begin{array}{c}\text { Hipotesis } \\
\text { diterima }\end{array}$ \\
\hline Kontrol & 17 & 63 & & & & \\
\hline
\end{tabular}

Dari hasil uji $\mathrm{t}$, menunjukkan $\mathrm{t}_{\text {hitung }}=2,23$ dan $\mathrm{t}_{\text {tabel }}=1,70$ pada $\alpha=0,05$ dan $\mathrm{dk} \mathrm{n}_{1}+\mathrm{n}_{2}-2=31$. Dengan demikian dapat disimpulkan bahwa $\mathrm{t}_{\text {hitung }}>\mathrm{t}_{\text {tabel }}$, maka $\mathrm{H}_{1}$ diterima dan Ho ditolak. Hal ini menunjukkan bahwa terdapat pengaruh yang signifikan dari penggunaan model pembelajaran kooperatif tipe STAD terhadap hasil belajar biologi pada siswa kelas X SMK N I Talamau. Dengan demikian hipotesis diterima pada taraf kepercayaan $95 \%$.

\section{PEMBAHASAN}

Hasil analisis data menunjukkan bahwa nilai rata-rata hasil belajar kelas eksperimen yang pembelajarannya dilakukan dengan model STAD adalah 73 lebih tinggi secara signifikan dibandingkan dengan hasil belajar kelas kontrol yang hanya 63, karena setelah dilakukan uji hipotesis dengan uji t, diperoleh $\mathrm{t}_{\text {hitung }}=2,23$ dan $\mathrm{t}_{\text {tabel }}=1,70$ berarti $\mathrm{t}_{\text {hitung }}>\mathrm{t}_{\text {tabel, }}$, maka hipotesis diterima pada taraf kepercayaan 95\%. Hal ini menunjukkan bahwa terdapat pengaruh yang 
signifikan dari penggunaan model pembelajaran kooperatif tipe STAD terhadap hasil belajar biologi siswa kelas X SMKN I Talamau Kabupaten Pasaman Barat.

Hasil analisis data ini juga telah membuktikan bahwa penggunaan model pembelajaran kooperatif tipe Students Teams Achievemen Division (STAD) lebih tinggi dibandingkan dengan pembelajaran konvensional. Tingginya hasil belajar siswa pada penggunaan model STAD ini mungkin disebabkan oleh tingginya minat dan motivasi siswa untuk belajar, karena pembelajaran dengan STAD, siswa belajar secara tim, sehingga kereka termotivasi karena mereka merasa segala susuatu beban dalam proses pembelajaran tersebut merupakan tanggung jawab secara tim, dengan tingginya minat dalam dalam belajar akan membuat kereka menyukai pembelajarannya, sehingga hal ini akan menjadikan siswa mudah dalam memahami materi yang dipelajarinya, sebagaimana yang dikatakan Lufri (2007:137) "Minat adalah kecendrungan yang dimiliki setiap orang atau individu untuk menyukai atau tidak menyukai sesuatu objek tertentu".

Selanjutnya (Sardiman 2010:102) mengatakan bahwa motivasi dan minat adalah sebagai keseluruhan daya penggerak didalam diri siswa yang akan menimbulkan, menjamin kelangsungan dan memberikan arah kegiatan belajar, setiap siswa memiliki minat belajar yang berbeda-beda, minat menentukan sukses atau gagalnya kegiatan sesorang. Minat yang tinggi akan meningkatkan motivasi, sedangkan kurangnya minat menyebabkan kurangnya perhatian dan usaha belajar, sehingga akan berpengaruh terhadap pencapaian tujuan belajar itu sendiri.

Model Pembelajaran STAD merupakan model pembelajaran yang menuntut siswa untuk melakukan kegiatan secara tim dan meminimalkan keterlibatan guru dalam memberikan pemahaman materi kepada siswa. Model pembelajaran STAD adalah model pembelajaran yang paling sederhana dan cocok untuk guru dan siswa yang pertama kali melaksanakan pembelajaran secara kooperatif.

Pelaksanaan pembelajaran dengan model STAD ini telah memuat siswa lebih memahami materi, ini terbukti dari tingginya rata-rata hasil belajar siswa di kalas yang pembelajarannya dilaksanakan dengan model STAD dibandingkan dengan kelas kontrol yang pembelajarannya secara konvensional, karena disini siswa belajar secara kooperatif, kompetitif dan individual. hal ini sesuai dengan apa yang dikatakan oleh (Lufri 2007:54 ) bahwa dalam mencapai tujuan pembelajaran, ada ada tiga macam struktur pencapaian tujuan pembelajaran yaitu individualistik, kompetitif, dan kooperatif.

Sebelumnya (Sanjaya 2006:246) juga telah menyampaikan bahwa prinsipprinsip dasar pembelajaran kooperatif adalah: perinsip ketergantungan positif, tanggung jawab perseorangan, interaksi tatap muka, partisipasi dan komunikasi. Hal ini terlihat diwaktu pelaksanaan pembelajaran, dimana siswa tidak tergantung dengan apa yang disampaikan guru, mampu untuk berpartisipasi dan berkomunikasi dengan teman, bahkan gurunya.

Pembelajaran STAD telah menjadikan siswa mengenal arah materi, para siswa bersemangat, karena setelah guru menyajikan materi, mereka diberi kuis dan bekerja sama dengan teman dikelompoknya, sehingga hal ini menjadikan mereka mempunyai motivasi yang tinggi dalam mengikuti pelajaran tesebut, sehingga mereka dengan mudah bisa menyerap materi dan diwaktu ditanya kembali mereka mudah mengingat kembali apa yang pernah mereka pelajari itu. Hal ini telah disampaikan oleh ( Istarni, 2014:20 ) bahwa pembelajaran kooperatif tipe STAD mempunyai kelebihan sebagai berikut: Arah pemebelajaran lebih jelas 
karena guru terlebih dahulu menjelaskan materi, suasana pembelajaran lebih menyenengkan karena siswa dikelompokkan, sehingga siswa diberi kesempatan untuk berdiskusi dalam kelompoknya, adanya kuis,sehingga akan memberikan arahan kepada siswa apa yang harus dipahaminya.

Sebaliknya pembelajaran secara konvensional, keterlibatan siswa dalam pembelajaran sangat rendah, siswa hanya menerima apa yang disampaikan oleh guru, seandainya siswa tidak dapat menyerap materi yang disajikan oleh guru, maka siswa tidak akan memahami materi tersebut, karena mereka tidak diberi kesempatan untuk berkomunikasi dengan kelompok belajaranya, dan juga kuis hanya akan ada setelah waktu nya ujian formatif dan sumatif. Disamping itu juga tidak ada kesempatan kepada siswa untuk belajar berkomunikasi dengan sesama teman dalam kelompok atau siswa dalam kelas untuk membicarakan materi pelajaran, sehingga, kalau seandainya ada siswa tidak bisa memehami meteri yang disampaikan guru, maka siswa hanya akan menyimpan ketidak pahamannya itu sendiri, sampai akhirnya mereka tidak akan dapat menjawab soal- sosal yang diberikan diwaktu kuis, sehingga hasil belajar mereka akan rendah bahkan tidak dapat menjapai KKM.

\section{KESIMPULAN}

Berdasarkan hasil analisis yang telah dilakukan, diperoleh $t_{\text {hitung }}=2,23$ dan $\mathrm{t}_{\text {tabel }}=1,70$ pada taraf nyata $0,05 \mathrm{dan} \mathrm{dk}=31$ yang artinya hipoesis diterima. Dari hasil analisis tersebut dapat disimpulkan bahwa terdapat pengaruh yang signifikan dari penggunaan model pembelajaran kooperatif tipe Students Teams Achievemen Division (STAD) terhadap hasil belajar biologi siswa kelas X SMK N 1 Talamau Kabupaten Pasaman Barat pada taraf kepercayaan $95 \%$.

\section{DAFTAR PUSTAKA}

Arikunto, Suharsimi. 2006. Prosedur Penelitian: Suatu Pendekatan Praktik. Jakarta: Rineka Cipta.

Arikunto, Suharsimi. 2015. Dasar-dasar Evaluasi Pendidikan. Jakarta: Bumi Aksara.

Harahap, Nurmahni. 2013. Penerapan Model Pembelajaran Kooperatif Tipe Stad Terhadap Hasil Belajar Kognitif, Motivasi, Dan Aktivitas Belajar Siswa Pada Konsep Ekosistem Di MTsN Model Banda Aceh. Jurnal pembelajran, Vol IV (02): 57.

Irsyad. 2012. Belajar dan Pembelajaran. Padang: FMIPA Universitas Negeri Padang.

Istarani. 2014. 58 Model Pembelajaran Inovatif. Medan: Media Persada.

Lufri. 2007. Strategi Pembelajaran Biologi. Padang: FMIPA Universitas Negeri Padang.

Musfiqon. 2012. Pengembangan media dan sumber belajar. Jakarta: Prestasi Pustakaraya.

Margono, S. 1996. Metodologi Penelitian Pendidikan. Jakarta : PT Rineka Cipta.

Pitria, Melka. 2011. "Penggunaan Pendekatan Cooperative Learning Tipe Student Team Achievemen Division (STAD) untuk Meningkatkan Hasil Belajar Siswa Pada Mata Pembelajaran IPS di Kelas V Sekolah Dasar Negeri 20 Tarok". Skripsi tidak diterbitkan. Jurusan Pendidikan Guru Sekolah Dasar Universitas Negeri Padang. 
Sudjana, Nana. 2005. Metode Statistika. Bandung: Tarsit.

Sugiono. 2015. Metodologi Penelitian Pendidikan. Bandung. Alfabeta.

Siregar, Eveline dan Nara, Hartini. 2014. Teori Belajar Dan Pembelajaran. Bogor: Ghalia Indonesia.

Syah, Muhibbin.2005. Psikologi Belajar. Jakarta: PT Raja Grafindo Persada.

Syah, Muhibbin. 2008. Psikologi pendidikan Dengan Pendekatan Baru. Bandung: PT Remaja Rosdakarya.

Sanjaya, Wina. 2006. Strategi pembelajaran berorientasi standar proses Pendidikan. Jakarta: Kencana.

Sanjaya, Wina. 2008. Perencanaan Dan Desain Sistem Pembelajaran. Jakarta: Kencana Prenada Media Group.

Sitompul, Lisnawati. 2014. Peningkatan Hasil Belajar Biologi Pokok Bahasan Ekosistem Melalui Model Pembelajaran Kooperatif Tipe STAD. Forum Paedagogik,Vol. VI (01): 91.

Sardiman, A.M. 2010. Interaksi dan motivasi belajar-mengajar. Jakarta: Rajawali Pers.

Trianto. 2009. Mendesain Model Pembelajaran Inovatif-Progresif: Konsep, Landasan, dan Implementasinya pada Kurikulum Tingkat Satuan Pendidikan (KTSP). Jakarta: Kencana.

Trianto. 2010. Model Pembelajaran Terpadu: Konsep, Strategi, dan Implementasinya Dalam Kurikulum Tingkat Satuan Pendidikan (KTSP). Jakarta: Bumi Aksara

Wahyuni, Annisa. 2014. "Pengaruh Model Pembelajaran Kooperatif Tipe STAD disertai Media Audio Visual Terhadap Hasil Belajar Biologi Siswa Kelas VIII SMPN 2 Kecamatan Harau". Skripsi tidak diterbitkan. Padang: program studi pendidikan Biologi STKIP Payakumbuh. 